\author{
HILDEGARDO CÓRDOVA-AGUILAR \\ Pontifical Catholic University of Peru, Lima \\ Center for Research in Applied Geography (CIGA-INTE) \\ hcordov@pucp.edu.pe
}

\title{
Reminiscences about Mariano Felipe Paz Soldán's Geographic Atlas of Peru (1865)
}

\begin{abstract}
Peruvian cartography in the nineteenth century was very rich and fulfilled the geographic knowledge demanded by the new Republic of Peru. In effect, the country of more than $1,000,000 \mathrm{~km}^{2}$ needed to show the physical environment and to locate the distribution of its natural resources. It was the time when cartography was valued as an element of empowerment and land control, especially when the political borders were rather unstable (G. Prieto 2018). Then, it was timely the publication of Atlas Geográfico del Perú (Geographic Atlas of Peru) by Mariano Felipe Paz Soldán, a prominent Peruvian lawyer and geographer. Author's purpose is to comment on the new edition of the Mariano Felipe Paz Soldán Atlas Geográfico del Perú, published in Lima in 2012.
\end{abstract}

Keywords: Peruvian maps in the 19th century, Paz Soldán Atlas

\section{Introduction}

The first cartographic information regarding Peru appeared during colonial times. In 1529 was printed the first map of Diego Ribero that shows the west littoral of South America where the coast of Peru is only partially delineated. In 1574, Diego Méndez (fig. 1), charged of a monastery in Lima and at the same time cosmographer of the viceroyalty of Peru, drew the map of Peru showing the Amazon region and its largest rivers, as well as the Andean drainage (H. Córdova-Aguilar 1993, p. 108; G. Prieto 2018). This interest in making maps continued in the 17th and 18th centuries to show the new territories discovered, especially those far away from Lima, such as the ones in the Amazon basin.

In 1775, appeared the Juan de la Cruz Cano y Ormedilla's Mapa Geográfico de la América Meridional (Geographic Map of Meridian America) in eight sheets. This map compiles all the information gathered in previous years including the maps that complement the reports of Jorge Juan and Antonio de Ulloa, Samuel Fritz, Charles Marie de La Condamine and Louis Feuillée. This compilation is so complete that according to R. Porras-Barrenechea (1963, p. 411) is "the best cartographic synthesis of that time".

In 1780 arrived to Peru the Alessandro Malaspina expedition that traveled the country making environmental studies and collecting plants and published several maps and charts. One of these was the plan of the city of Lima and its surroundings titled Plano del Fondeadero del Callao y Costas Inmediatas desde la Punta de Chilca hasta el Cerro de la Arena en el Puerto de Ancón (Plan of Callao Anchorage and immediate coasts from the Chilca Punta to la Arena hill in the Ancon harbor0 (1790) (H. Córdova-Aguilar, 1993, p. 110).

To these expeditions we may add the ones made by the Jesuits and Franciscans who entered to the eastern jungle. They drew maps such as the one by Father Samuel Fritz on the Marañón River and the maps of Fathers Manuel Sobreviela and Narciso Girbal on the Ucayali and Huallaga rivers.

In the 19th century the flow of European naturalists was eased, especially after the independence of Peru from Spain. During the 1830 s and 1840 s many scientific expeditions visited Peru who went to the Sierra and Jungle; 


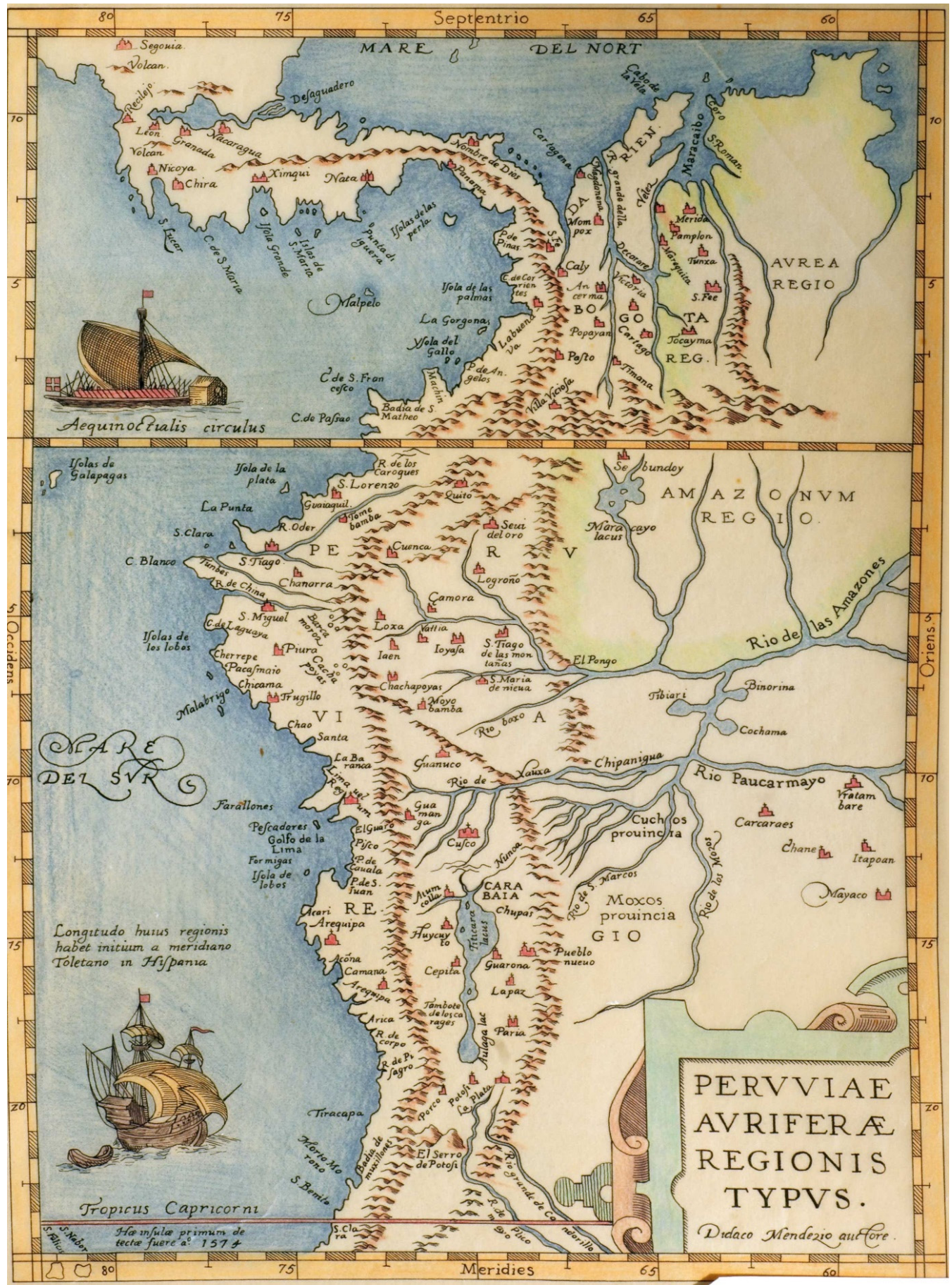

Fig. 1. Peruviae Auriferae Regionis Typus by Diego Méndez (source: https://commons.wikimedia.org/wiki/ File:Peruviae_Auriferae_Regionis_por_Diego_M\%C3\%A9ndez_1574_-_AHG.jpg) 
such as the one of William Smith and Frederick Lowe to the Huallaga, the Germans Eduardo Poepping, Francisco Julio Fernando Meyen and José Barclay Pentland to the Altiplano of Puno and the anthropologist Alcide Dessalines d'Orbigny who visited Peru and Bolivia. All these expeditions presented their reports illustrated with maps (R. Porras-Barrenechea 1963, p. 425).

In 1840 Gregorio La Rosa, drew a Croquis del Departamento de La Libertad y del Gobierno Litoral de Piura (Sketch of La Libertad department and of the littoral Government of Piura) and a Carta de la Montaña de Chanchamayo (Map of the Chanchamayo mountain) (R. Porras-Barrenechea 1963, pp. 428-429).

\section{Atlas Geográfico del Perú (1865)}

All this synthetic information is to say that by the 1860s there was already plenty of geographical information that needed to be systematized to be usable by the Government officials and scientists interested in the Peruvian development. Thus, in 1865 it was published in Paris the Atlas Geográfico del Perú (Geographic Atlas of Peru) of Mariano Felipe Paz Soldán ${ }^{1}$. This atlas was of much utility and it was the only one in the libraries for the next 35 years until the Raimondi map was incorporated as the official map of Peru. According to its author, this map was the result of 21 years of research on the history and geography of Peru. Previously he published in 1856 a Map of Peru based on information given by A. Malaspina to the littoral, W. Smith and F. Lowe to the Huallaga, E. Poepping, F.J.F. Meyen and J.B. Pentland to the Altiplano of Puno. He made some corrections

\footnotetext{
1 After the Independence from Spain in the 1821 the new republics were filled of political ambitiousness and had the need to justify their existence. Thus, they needed cartographic information and the atlases and maps were a good way to fill this gap. Thus, it appeared the Atlas físico y político de la República de Venezuela (Physical and political atlas of the Venezuela Republic) published in Paris, 1830, considered as the first Latin American modern atlas. It is a compilation of maps, population and its economic characteristics as well as a recount of historic events (https://www.geografiainfinita. com/2017/04/la-historia-de-colombia-a-traves-de-los-mapas/). This atlas includes a map of Colombia by Agustín Codazzi, the Colombian engineer who started a series of maps and atlases of the Republic of Colombia. Claudio Gay made maps of Chile in the 1830's; and Mariano F. Paz Soldán made another atlas of the Republic of Argentina in the late 19th century. Then, we may say the art of making maps and atlases was a South American tendency.
}

and incorporated new astronomic observations to places not registered yet. This map was honored in the World Exposition of Paris in 1867.

There is a curiosity to learn why these publications were made in Paris and not anywhere else. During the 19th century Paris was the world cultural centre and attracted people from all over the world like New York is after de World War II. Then, it was rather normal for many of the Peruvian elite to live in or visit France. They established overseas economic and political ties that facilitated the cultural interactions. On the other hand, the Paris printing ateliers at that time had a renowned name. They had a well developed technique of printing maps copper plate and map reproduction. Thus, not only the Peruvian atlas and books were printed in Paris but others like the ones of Codazzi for Colombia.

The first edition of the Atlas Geográfico del Perú (Geographic Atlas of Peru) was printed in Paris in1865 at the Bookstore of Firmin-Didot Brothers, Son, and Co. It was organized in two parts: The first one gives information on the ways how the author gathered the information for the atlas, carefully indicating the degree of assertiveness. He dedicates some pages to list the geographic positions of some places in the country, their elevation above sea level, the distances along trails between places in each department that may be useful to travelers, discussion of the degree of confidence on the observations, magnetic observations, climatic conditions and the political division of Peru. The second part includes 68 maps, among which there are 13 department maps - Amazonas, Piura, Cajamarca, La Libertad, Ancash Junín, Lima, Huancavelica, Ayacucho, Cuzco, Puno, Arequipa, Moquegua, three littoral provinces - Loreto, Callao, Ica - with plans of their capitals and other important urban centres, a mineralogical map of Peru $^{2}$ (fig. 2) and several topographic profiles. Besides, it includes some photos of churches, landscapes, and carbon draws of native persons of the Andes. Of course, the drawings are only approximations since they do not bring scale and the administrative limits are too simplified. As an example let's

2 The maps included here are copies of the original and there are no other maps. The scales are given in leagues per geographic degree, which was used at the time when the atlas was printed. 


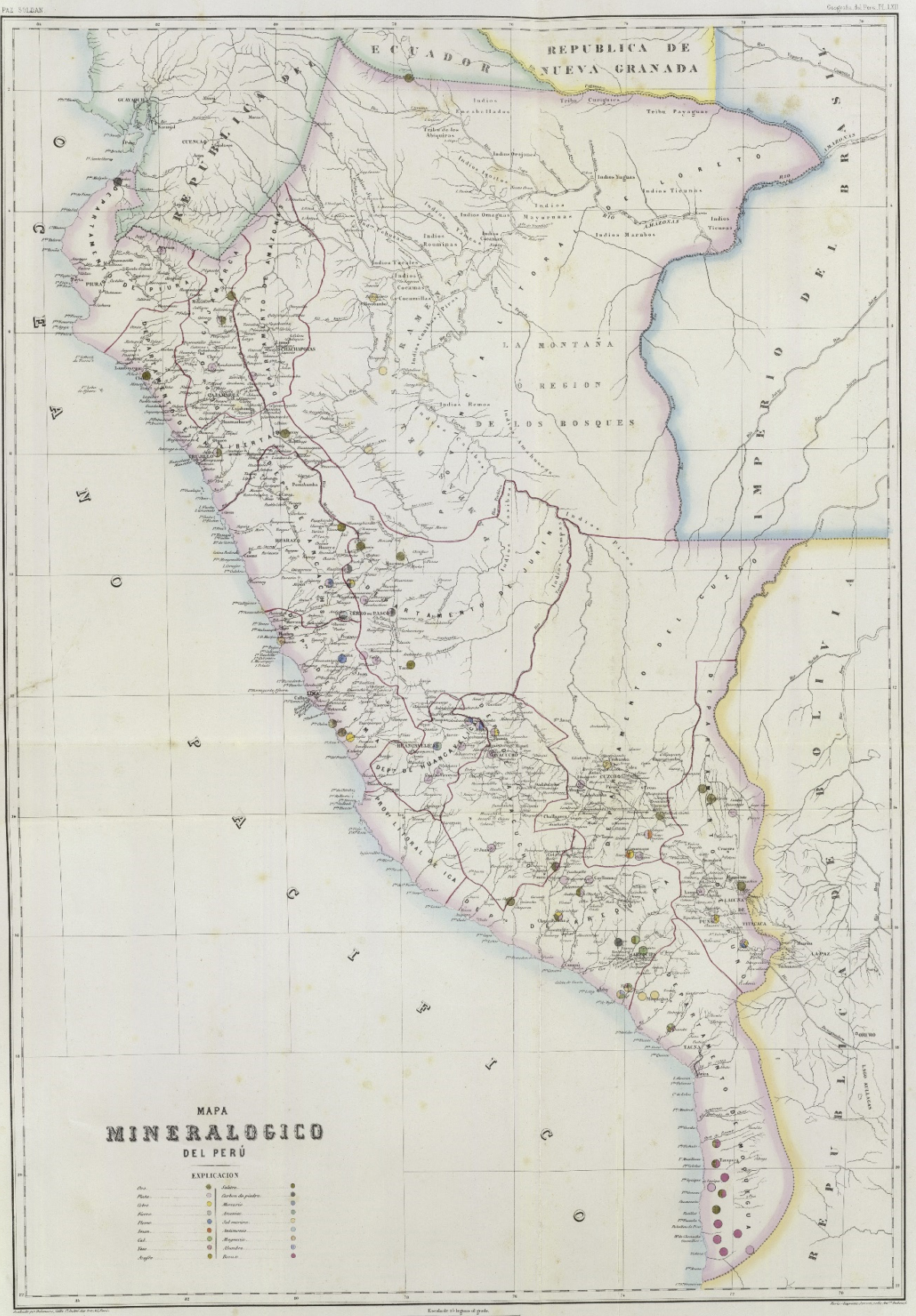

Fig. 2. Mineralogical map of Peru by M.F. Paz Soldán (source: David Rumsey Map Collection. https://www.davidrumsey.com/luna/servlet/view/all/who/Paz+Soldan,+Mariano+Felipe,+1821-1886?os=0) 
see fig. 3 where the department of Cajamarca is showed in the 1865 version and the contemporary shape.

A note of the David Rumsey Map Collection regarding the Paz Soldán's Atlas geográfico del Perú says that this "atlas exudes the optimism of the period" (https://www.davidrumsey. com/luna/servlet/detail/RUMSEY 8 1 20562 570087:Mapa-general-del-Peru-?sort=pub_ list_no_initialsort\%2Cpub_date\%2Cpub_list_ no $\% 2$ Cseries_no\&qvq=q:atlas $\% 2 B p a z \% 2 B-$ soldan;sort:pub_list_no_initialsort\%2Cpub date\%2Cpub_list_no\%2Cseries_no;Ic:RUMSE $\bar{Y}$ $\sim 8 \sim 1 \& \mathrm{mi}=42 \&$ trs $=116$ ). In fact, that was the time when the South American countries were competing each other to gain lands at their borders where population settlements were scarce.

It seems there was more than one copy printed, because the Rumsey Map Collection note mentions there were two Spanish issues made in the same year in Paris with different inscriptions in the first page; Durand also published a Paris edition in French in 1865.

\section{A new edition of the Atlas (2012)}

The new edition (2012) was published by a joint effort of the National University of San Marcos of Lima (UNMSM), the Embassy of France in Lima, and the French Institute of Andean Studies (IFEA). The argument of this new edition, 150 years after its first printing is to make justice to a prominent Peruvian still ignored by many of his nationals and to revitalize the history of the Peruvian cartography (Foreword of the new edition).

The atlas size of $42 \times 33.5 \mathrm{~cm}$ is $20 \%$ less than the original format. It has 82 text pages, plus 10 initial ones with foreword commentaries regarding the atlas by George Lomné, Director of IFEA and Waldemar Espinoza-Soriano, Dean of the Faculty of Social Sciences at UNMSM. There is also an introduction with a brief commentary of the great atlases of the 19th century, the one of Paz Soldán, and Raimondi, expanding to the contemporary cartography lead by the National Geographic Institute by Carlos Peñaherrera del Aguila. Next, Jean-Pierre Chaumeil (CNRS/IFEA) writes about Mariano Paz Soldán and the advancement of the geographic science in decimononic Peru. Manuel Delgado Estrada writes another article about the construction of geographic thinking in Peru in the 19th century through the academic production of Mariano Felipe Paz Soldán.

Jean-Pierre Chaumeil argues that Mariano Felipe Paz Soldán was descendant from a family that moved from Panama to Arequipa in the last quarter of the 18th century. He was part of an educated family and worked as judge and also as a public deputy during the government of Ramón Castilla; Ministry of War and Foreign Relations during the governments of José Balta, Mariano I. Prado and Luis La Puerta. He managed to fulfill his political responsibilities with the geographic research. During the Chilean-Peruvian war he was expatriated to Argentina and there he edited an Atlas geográfico de la República Argentina (Geographic atlas of the Republic of Argentina) and a Diccionario geográfico estadístico nacional argentino (National geographic statistic dictionary of Argentina) (1885). Chaumeil also notes that most of the writings on M.F. Paz Soldán refer to him as an historian, especially due to his Historia del Perú Independiente (History of independent Peru) and very little is left for the geographer, maybe because this category was given to Antonio Raimondi, a prominent naturalist of that time. The Geografía del Perú and the Atlas Geográfico del Perú printed in Paris were paid by the Peruvian government, because both works were considered fundamental as they synthesized all geographic knowledge available in libraries and archives up to that time. In effect, M.F. Paz Soldán himself confessed that to write his Atlas, he had consulted the works of Alejandro Malaspina and others, including the fieldwork data of Antonio Raimondi.

J.P. Chaumeil's paper (2012) is interesting because it goes further to search the origins of maps and views published in the Atlas Geográfico del Perú. He found that several views were first time lithographed of photos taken by Émile Garreaud and William G. Helsby. M.F. Paz Soldán ordered the engraving of the sheets of maps and photos for his atlas in Paris based on the Garreaud's clichés. He recommended his people' sheets to the ethnographers because they would give a better idea than any other description. J.P. Chaumeil also says that there were two similar editions of the Atlas printed in Paris in 1865. The first was made by the editorial house Firmin-Didot Frères and the second by editorial house Auguste Durand and printed by A. Lainé and J. Havard. The latter was in 


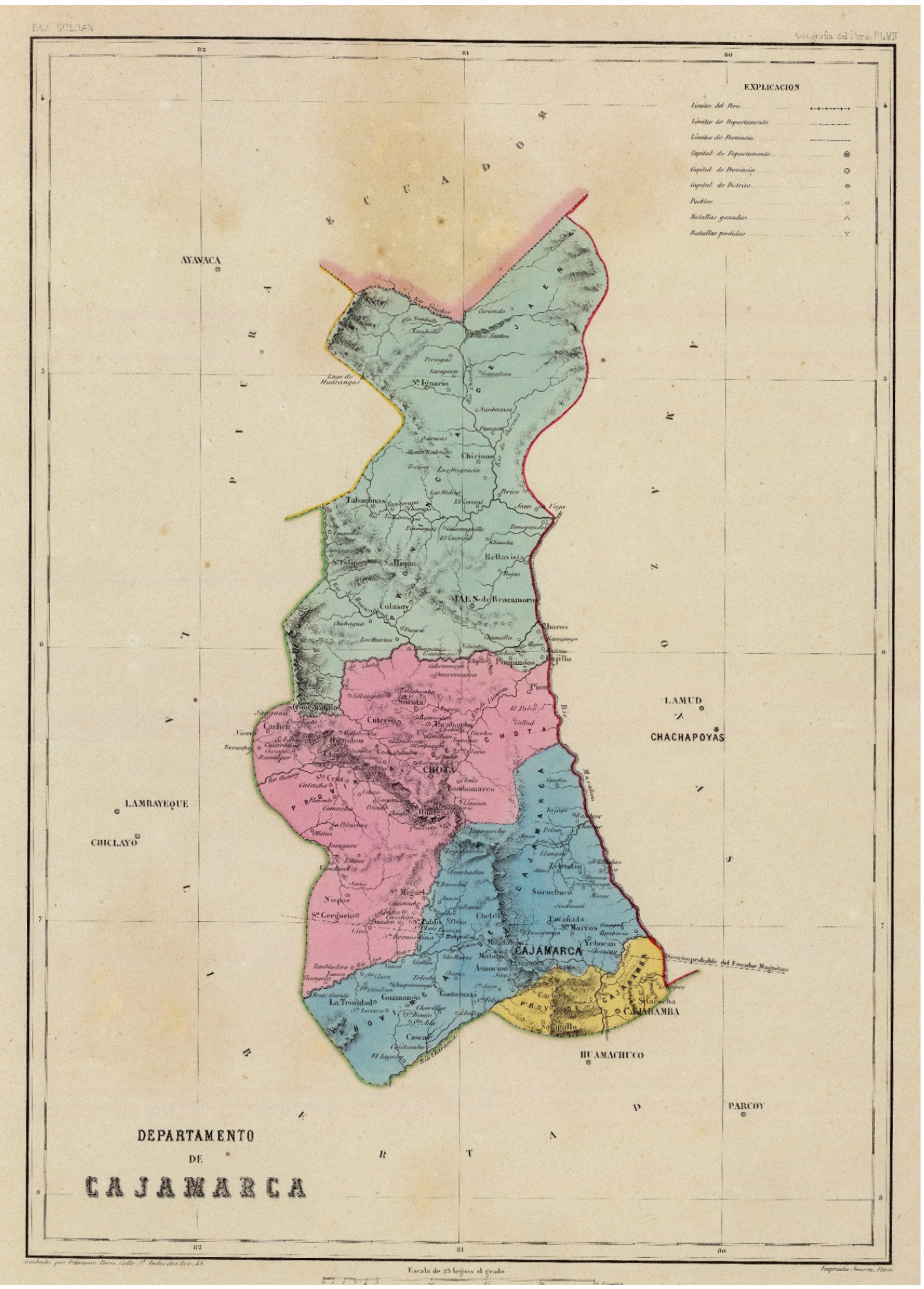




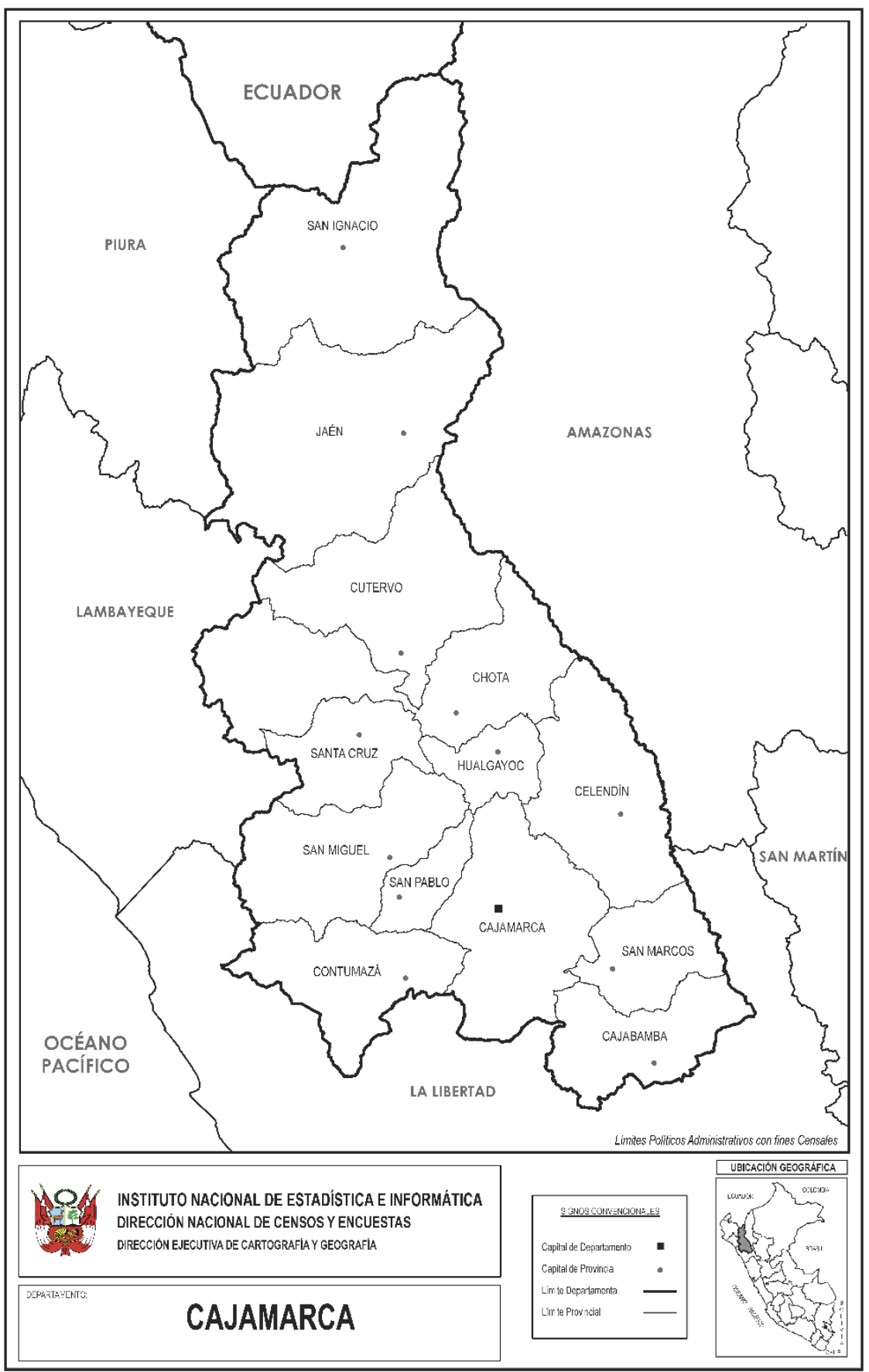

Fig. 3. View of the department of Cajamarca according to M.F. Paz Soldán and the actual department of Cajamarca (sources: David Rumsey Map Collection https://www.davidrumsey.com/luna/servlet/view/all/who/Paz+Soldan, +Mariano+Felipe,+1821-1886?os=0; INEI https://www.inei.gob.pe/media/MenuRecursivo/publicaciones_digitales/Est/Lib1159/cuadros/cajamar/cajamar_6_1.pdf) 
French, titled Atlas géographique de la république du Pérou.

The paper written by L.M. Delgado-Estrada (2012) titled La contributión del pensamiento geográfico del Perú en el siglo XIX a través de las obras de Mariano Felipe Paz Soldán (The contribution of the geographic thought of Peru in the 19th century through the works of Mariano Felipe Paz Soldán) is a geopolitical approach trying to explain the geographic thinking of the Paz Soldán brothers (Mateo and Mariano) at the mid nineteen century. He argues that geography in the 19th century was synonymous of cartography. That the young Republic of Peru needed an inventory of the topographic sheets carried out by Clemente Althaus, the antecessor of Mariano. Peruvian intellect during the second half of the 19th century was mostly provincial and dependent on the international knowledge centers. In general, Peruvian intellectuals were specialists in generalities and idealized sceneries. They were not open to new ideas about the State and his relation with social groups that looked for territorial justice. Then the Peruvian leadership was involved in developing a new colonialism structure. It was in this sociocultural environment where Mariano I. Paz Soldán prepared his Atlas. The building of the Peruvian identity by the modern State through the Mariano's Atlas was to try to homogenize the hostile territory to the new hegemonic body in the government and to create an image of unity with a topophilia. J.H. Delgado-Estrada argues that the Atlas geográfico del Perú shows the influence of the environment on the people in very indirect and complicated ways, closely related to human ideas about religion, economy, politics, war, etc., following the determinist geographic tradition of that time. This statement is not showed as valid in reading the literature of the author, who was strict in checking the information sources and their impacts. I think the limits are not imposed by the environmental conditions but due to the limits of geographic knowledge. Paz Soldán says in clear statements that his atlas is the result of a long an patient data collection, searching to many archives and documents in the ministries and he takes care of crediting the corresponding authors. Such is the case when he locates places by latitude and longitude, their height, and magnetic observations.

Pascal Riviale (2012) also wrote an interesting article titled "Impreso en Paris" La contribución de los talleres franceses a la cartografía peruana en el siglo XX ("Printed in Paris". The French printing houses' contribution to the Peruvian Cartography in the 20th century). He argues that the art of making maps and plans about different sections of the Peruvian territory was made by Frenchmen in the 18th century. These were the result of explorers such Father Feuillée, Amédée François Frézier or C.M. de La Condamine and his colleagues of the Academy of Sciences; and copies of Spanish maps. But it was in the 19th century that cartographic production about Peru was intensified with maps, atlas and geographic compendiums. Then, several Parisian printing houses had the chance to work for the Peruvian government. Such is the case of the first version of the Plano topográfico de la ciudad de Lima (Topographic plan of the city of Lima) drawn by Antonio M. Dupard in 1859, engraved by Georges Erhard Schièble and printed at Hedin's house.

At that time, all important scientific publications of Peru were printed in France. Thus, $P$. Riviale goes on his recounting of events and says that the book Geografía del Perú (Geography of Peru), whose initial authorship was Mateo Paz Soldán who died in Lima in 1857, was introduced to the Geographic Society of Paris for publication by his brother Mariano Ignacio, who took over the responsibility to publish it. Then, he traveled to Paris in 1861 and decided to finish the first volume under the same title, which was published in Paris by Firmin-Didot Frères in 1862. Next, Mariano thought in a more ambitious project which was to accompany the Geografía del Peru with an atlas of maps and vignettes. To do this, Mariano prepared some of his own designs and also collected information gathered by other Peruvians.

P. Riviale's findings give us more detailed information of the process followed to publish the atlas, which was a scientific and artistic document. For example, he says that the first sheet of the atlas appeared in November 15, 1862 titled Plano que manifiesta los reconocimientos de caminos hechos en el departamento de Amazonas (Plan showing the recognizance of trails made in the department of Amazonas) by Montferrier; it follows a plan of the city of Chachapoyas (Nov. 13); plan of the city of Cajamarca (Dec. 20); plans of the cities of Lambayeque, Piura and Huaraz and the map of the department Amazonas (Jan. 7, 1863); plans of Tacna and Puno (Feb. 10); plans of Islay and 
Pisco, and the penitentiary of Lima (March 9); plan of the city of Chorrillos by Dupard (March 14); Plan of Ica (March 16); plan of the exploration of four routes from Lima to Jauja and Pasco, and the plans of Tarapoto and lquique (April 24); plan of Trujillo (April 20); plans of Ayacucho and El Callao (May 27): plans of Tarma and again Ayacucho (June 22); plans of Moyobamba and Huancavelica (July 4); topographic plan of Cerro de Pasco (Oct. 6); plan of the city of Lima and map of the littoral province of Ica (Nov. 21); plans of the cities of Arequipa, Huancavelica and Cuzco and map of the department La Libertad (April 12, 1864).

There are other topics discussed in this Atlas, such as the concept of climate as the set of conditions that determines the degree of heat at each place. He states that the origin of heat comes from the sun but there are other factors that disturb the regularity of its distribution on the earth. Among these factors are latitude, altitude, wind blowing, and the Andes Mountains. Then he introduces practical explanations on the temperature difference among places at the same latitude but different altitude. This leads to the Andes, which in Peru bifurcate in two chains, and is responsible for the climatic variety that is grouped in three natural regions: Coast, Sierra and Mountain. There are not indications of altitudinal boundaries among regions, just their main morphologic characteristics and the range of temperature change during day and night. He also includes some information on the teritory of Peru, which he calculated by dividing the country into 14 latitudinal zones and measuring each areas by using triangles, squares or polygons and calculated the areas in square leagues. His calculation gave 1,605,742 $\mathrm{km}^{2}$. However, using the Spanish league officially accepted at that time of $5.5727 \mathrm{~km}^{2} /$ league, the total area of Peru would have been $1,616,412 \mathrm{~km}^{2}$. Finally, in this section Paz Soldán inserts a table with the political division of Peru that comprises 13 departments, 3 Littoral provinces, 76 provinces and 700 districts according to the 1862 census.

\section{The General Map of Peru (1856)}

Scale: 25 leagues/degree or ca. 1:1,000,000, $140 \times 210 \mathrm{~cm}$, Engraver F. Delamare. Relief by shading and hachures, forests by tree symbols.
As M.F. Paz Soldán says in the introduction of his Atlas, the object of this map was to give geographers the real information about the land characteristics of the country. To include in the map all the names of towns, hamlets, etc, etc, of the Republic would have brought confusion instead of usefulness. Rather he chose to make a map that gives a general view of Peru where only departments and districts are included. The map was published in six large sheets in 1864.

This map is important not only because it was the first one of Peru as independent country showing the boundaries with her neighbors, but also for the drawings around the map. For a better understanding of the symbolic representation of these drawings, let's follow H.F. Paz Soldán explanation to the issue. He starts by saying, at the center up are the figures of the coat of arms of the Republic; to the right is the city of Lima represented by a woman holding a lima fruit; to the left is Arequipa symbolized by a woman holding a bread at one hand and a shovel at the other, because agriculture is very well developed there and the wheat production is abundant too. At the right of Lima, is the view of the Santa Rosa town located at the junction of the Tambo and Urubamba rivers that form the Ucayali River. The vignette at the corner is a general view of Lima from the San Cristobal hill; at its top are the toucan bird (Ramphastus ${ }^{3}$ ) and the vizcacha (Lagidium peruvianum). To the right of the general view of Lima is the climbing vine called vanilla ( Vanilla aromatic).

Continuing in descending sense, it is the condor (Sarcoramphus grypus) king of South America birds that normally flights above $4,000 \mathrm{~m}$ and sometimes reaches $7,000 \mathrm{~m}$ above sea level. It flies in steep movement over the rattle snake (Crotalus horridus) that is coiled up at a palm tree (Cocus butyracea); in the vignette aside is the chinchilla (Eriomys chinchilla) whose furs are an important export gods, and the coati (Nasua montana). In back are some antiquities of the Altiplano, near the Titicaca Lake; and to the right it is corn (Zea mais).

In the vignette aside are the main fruit products of Peru, such as banana, cherimoya (Annona cherimifolia), potato (Solanum tube-

\footnotetext{
3 All scientific names inserted in this text are the ones originally printed in the Atlas.
} 


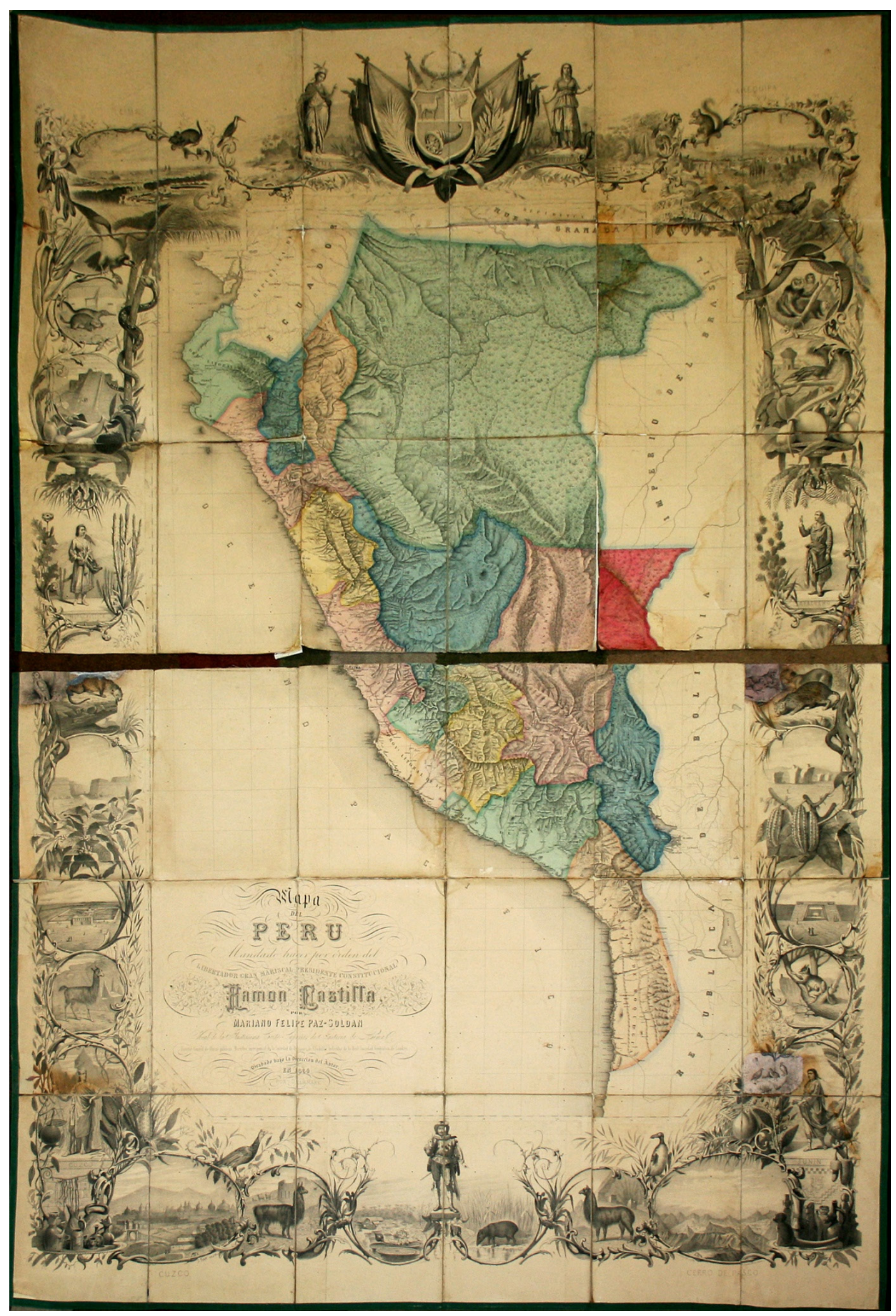

Fig. 4. Map of Peru by Mariano Felipe Paz Soldán (source: Barry Lawrence Ruderman Antique Maps, Inc. https://img.raremaps.com/xlarge/30727.jpg) 
rosum); in the background are some antiquities of the town Carumba, located seven leagues from Andahuaylas. Just in the same direction there is Huancavelica represented by a woman wearing a mercury coat, which is the main richness of the department. The coat has the number 76 that is the price for one quintal of mercury. To the right is the cardo santo (Argemone mexicana) that may characterize the coastal Peruvian flora; and to the left is the gigantón (Cactus peruvianus) endemic to the cordillera. Below it appears the puma or Peruvian lion (Felis puma) and below it is coffee (Coffea Arabica) with some antiquities at the back. The Lima penitentiary is next, as one of the Peruvian monuments. The lower figure represents the vicuña (Camelus vicugna).

The lower vignette represents Cuzco with the Inca as symbol, capital and cradle of the Incas Empire; to the right is the Strichnos brachiate used to prepare a poison called Ticuna. To the left of Cuzco there is Cascarilla (Chinchona riveroana). At the bottom and corner of this big frame there are the huaqueros (grave robbers), quipos and other things. Behind the Inca is the Ollantaytambo fortress.

At the left of the bottom band, after the huaqueros, is a view of Cuzco. Above it and to the corner, left of the vulture (Cathartes urubu) is the pineapple (Bromelia ananas). To the left of the view of Cuzco is the llama (Camelus lama) a representative of the New World ruminants. The vignette aside is Nauta, a jungle town located at the confluence of Ucayali and Marañón to form the Amazonas. On its waters lives the giant Victoria regia.

In the lower centre of the frame is the ancient Intendancy of Trujillo represented by a Spaniard. The mammals aside is a tapir (Tapirus americanus) and alpaca. The great corner vignette is Cerro de Pasco, the richest mineral settlement of Peru; and above it is the Pájaro Niño (Spheniscus Humboldtii) the main guano producer.

Following from the bottom up of the right side of the frame there is above the huaqueros the Junin Intendancy symbolized by a woman holding a silver bar because mining is the principal economic activity of that department. The number 11.22 is imprinted in the bar and it means the silver law at those mines. To its left is the elegant and dangerous Habilla or Ajuapar (Ura crepitans) and to the right the coca plant
(Erythroxylon coca). Above Junín is the Sariga or Muca (Didelphis sariga) a New World marsupial; the draw at the back is an antiquity from the Marañón. Next above is the Huánuco Viejo ruin. Aside the Sariga is the chamico (Datura stramonium) and to the right the hevea leaves (Sphonia elastica).

Above the Huánuco Viejo ruin is the cacao (Theobroma cacao) aside the ocelot and jaguar (Felis uncia). The symbol of the Intendancy of Huamanga is an Indian who holds a coin in his hand and other jewels and wears a cloth for cold weather. On its right is the tuna (Opuntia tuna) which hostess the cochinilla one of the main products of the department. At the left are war weapons used by the jungle people. Above the figures just mentioned are some fruit, such as the papaya (Carica papaya), aji pepper (Capsicum annum), further up is the anteater (Myrmecophaga tamadua), and the sloth bear (Bradypus trivittata), the spider monkey or chuva (Ateles marginatus), marimunda (Ateles ater), boa or yacumama (Boa constrictor) and the gallo de las rocas (Rupicola peruviana). The previous frames are enclosed by the banana.

Finally, there is a nice view of Arequipa at the superior section of the frame; to its left hangs up the granadilla (Passiflora ligularis) and above it there is a squirrel (Sciurus), an owl and several butterflies.

After the explanation of the map frame symbols, let's say something on the General Map of Peru. It represents a tremendous effort in delineating the political divisions of the country as well as the hydrographic systems, with names of localities and cordilleras, including the jungle section which at that time was still an exotic land. Paz Soldán made a very fine delineation of the coastal littoral but he couldn't do the same detailed information with the international borders where there are sectors that appear to be empty spaces, especially in the Easter side. Important names as Iquitos and Pucallpa are not shown. The density of place-name locations shows a central distribution from Lima to the exterior, which is part of our ancient problem of centralism that J. Matos Mar (2012) referred in the late 20th century as "Lima is Peru" meaning that everything is concentrated in Lima leaving the rest of the country abandoned. We have more detailed information of the geographic aspects closer to us; and the international borders are far away from Lima 
and our vision of those territories is even now, open to imagination.

\section{Concluding comments}

It has been worth to have this Atlas new edition with the necessary comments by its editors. This edition published jointly by the French Institute of Andean Studies and the Editorial Fund of the National University of San Marcos allows preserving the Paz Soldán Atlas and making it accessible to Peruvian readers. The worthiness of this atlas is that it gave a tool to Peruvians to build their identity attached to a territory. The information given there was es-

\section{Literature}

Chaumeil J.P., 2012, Mariano Felipe Paz Soldán y el avance de la ciencia geográfica en el Perú decimonónico. In:Atlas Geográfico del Perú por Mariano Felipe Paz Soldán. Eds. J.P. Chaumeil, J.M. Delgado-Estrada. Lima: Fondo Editorial UNMSM, Ambassade de France au Pérou, IFEA.

Chaumeil J.P, Delgado-Estrada J.M., (eds.), 2012, Atlas Geográfico del Perú por Mariano Felipe Paz Soldán. Lima: Fondo Editorial UNMSM, Ambassade de France au Pérou, IFEA.

Córdova-Aguilar H., 1993, La percepción geográfica del Perú entre 1790 y 1880. "BIRA. Boletín del Instituto Riva Agüero” N²0, pp.107-116.

Delgado-Estrada J.M., 2012, La contribución del pensamiento geográfico del Perú en el siglo XIX a través de las obras de Mariano Felipe Paz Soldán. In: Atlas Geográfico del Perú por Mariano Felipe Paz Soldán. Eds. J.P. Chaumeil, J.M. Delgado-Estrada. Lima, pp. IX-X.

Matos Mar J., 2012, Perú. Estado desbordado y sociedad nacional emergente. Lima: Universidad Ricardo Palma, Fondo Editorial. sential to decision makers who were mainly "limeños". The original edition has almost disappeared and some copies are only found in libraries and incomplete. The editors of this new edition mention that they had difficulties in getting all maps and are not sure if pages 55 and 56 of the original are white pages or two maps missing. It is also important to mention that the original atlas size was $53 \times 43 \mathrm{~cm}$ which is more difficult to handle than this new edition of $42 \times 34 \mathrm{~cm}$.

Of course, other Peruvian atlases with new techniques and better knowledge of the territory have been published in the twentieth century. But that may be a discussing topic for a new paper.

Paz Soldán M.F., 1856, Mapa del Perú. Mandado hacer por orden del Libertador Gran Mariscal Presidente Constitucional Ramón Castilla por Mariano Felipe Paz-Soldán, Vocal de la Ilustrísima Corte Superior de Justicia de Lima, Director General de Obras Públicas..., ca. 1:1,000,000. Paris.

Paz Soldán M. F., 1865, Atlas Geográfico del Perú. Paris. Porras-Barrenechea, R., 1963, Fuentes históricas peruanas. Lima: Universidad Nacional Mayor de San Marcos.

Prieto G., 2018, La evolución de Perú a través de los mapas. https://www.geografiainfinita.com/2018/01/ peru-a-traves-de-los-mapas-antiguos/ (access 20.04.2018).

Riviale P., 2012, Impreso en Paris: La contribución de los talleres franceses a la cartografía peruana en el siglo XIX. In: Atlas Geográfico del Perú por Mariano Felipe Paz Soldán. Eds. J.P. Chaumeil, J.M. Delgado-Estrada. Lima, pp. XI-XII.

Temple-Aguilar E.D., 1978, Panorama geográfico del Perú en 1839. "Boletín de la Sociedad Geográfica de Lima” XCVIII, pp.16-18. 